\title{
ROMANTISMO NO SÉCULO XX
}

\begin{abstract}
Maria Luicia Fernandes Guelfi *
Para Antônio Cândido, o mestre que me inspirou estas rellexōes.

I saw the best minds of my generation destroyed by madness.

RESLMO

Paralelo cutre poctas dos anos $60 / 70$ c poctas do Romantismo, cujos traços comıns sc däo con contevos hisıóricos inurcados pelas transfonmaşócs pollti-

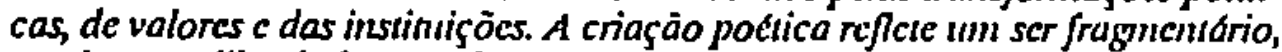
que busca a liberdade, usando a arte como anna de luta. Rebeldia quic, cal un novo mal do século, volta-se por vezes d auno-destniçāo. Tais elchnchtos, presentes não só nos movimentos da Contracultura e possia maryinal, mas no comportamento, tontam as experíncias vitais mais marcantes quc a heranço artstica, $\mathrm{cm}$ iórios dos casos apontados.
\end{abstract}

(Allen Ginsherg)

Unilermos: Romantismo; poesia social; arte engajada; contraculhura; Centro Poptular de Culture.

Na clécada de 60 do século passado vamos encontrar nosso Castro Alves pondo aqueles versos sonoros e grandiloqüentes a serviço de uma causa humanitária que até hoje nos comovc: o Abolicionismo. Na década de 60 do século atual, os poetas ligados ao CPC (Centro Popular de Cultura) fazcm poesia para conscientizar as massas de que ainda vivem em plena escravidāo, cspoliadas pelas classes dominantes, tentando levá-las à luta de libertaçāo. Qual a semelhança entre as duas geraçōes?

Suscitando o sonho de harmonia $\mathrm{c}$ igualdade, o Romantismo gerou uma utopia social. Revolucionário por naturcza, o pocta román-

* Prof" de Litcratura Brasileira na Universidade Federal de Viçosa-MG. 
tico pode ser definido como aquele que repudia as convençōes sociais, as injus tiças, tudo o que prejudique os direitos do indivíduo. Nem sempre, porém, ele encarna o papel de herói, portador da elevada missão de transformar a sociedade. Nāo raras vezes, esse poeta incorpora a rebeliāo de forma destrutiva. Extravazando tudo o que estava reprimido nos porões do inconsciente, encontra outra maneira de se livrar da opressão da sociedade, levando o negativismo às últimas conseqüencias. Essa tendéncia, conhecida por mal do século, levou muitos jovens à autodestruiçāo.

No final da década de 50 e início da seguinte, descrentes do capitalismo e do socialismo, os jovens da Beat Generation pregavam nova saida: a contracultura. Drogas, filosofias orientais, rock eram os novos ingredientes da luta, armas "pacíficas" para a destruiçāo da sociedade capitalista. Mas esse novo surto de mal do século acabou na destruiçāo dos próprios jovens. Foram muitos os que empreenderam a mesma viagem sem volta ao mundo do vício, da loucura e do suicídio. O que tinham eles de romântico?

Segundo Schlegel, mestre de rodos os românticos, foi o sentimento do-pecado que, levando ao dilaceramento interior, marcou o fim do Classicismo pagão e o início do Romantismo. A visăo que o romântico tem do homem é de um ser cindido, fragmentado, dissociado. Daí o sentimento de inadequação social e o sentimento negativo de angústia e niilismo, bem como, do ponto de vista formal, a adoção do "fragmento". A fragmentaçāo do texto, depois de ter exercido fascínio entre os românticos, volta a ser mania entre poetas e narradores, na literatura experimental dos anos 70 no Brasil.

\section{Romantismo e revoluçăo}

Atmosfera revolucionária, que cnvolveu todos os setores da sociedade ocidental, o Romantismo ultrapassou a csfcra da cstética, podendo ser detectado tambem nas ciências e na vida economica, na religiāo e na política. A mentalidade romántica, que tinha no pensamento de Jcan-Jacques Rousscau um dos scus fundamentos, incitava a uma prática rebelde, modificando comportamentos e criando linguagens.

Como estilo de época, ć impossível comprecnder o Romantismo sem situá-lo naquele momento de construção da socjedade moderna, cntre a Revolução Francesa e a Revolução Industrial, quando institujçōes políticas tradicionais, como o absolutismo, sofrem fortes abalos, cedendo terreno a novas aspiraçöes, permeadas todas clas por novas idcologias, como o nacionalismo, e novas teorias acerca do Estado. Aos poucos todos os povos começarn a sonhar com o progresso social.

No período que se estende de 1770 a 1848 , há uma intensa agi- 
tação revolucionária, de formidável influência na história das Américas e da Europa. A crista dessa onda foi a Revoluçāo Francesa, cujos programas, enfatizando idéias de liberdade e igualdade para os indivíduos, levam a história ocidental a caminhar num rumo socializante. Camadas marginalizadas da sociedade começam a participar das decisōes polfticas ligadas ao seu destino.

A Revolução Francesa năo aboliu a desigualdade entrc us homens, cada vez mais profunda na sociedade moldada pela Revoluçăo Industrial, mas suscitou a preocupaçăo em criar condiçōes para o surgimento de uma sociedade harmoniosa e justa. Nessa época surgem muitas teorias precursoras do socialismo. Trata-se ainda de um socialismo bastante idealista, cheio de piedade pelos pobres, mesclando ética social com ética religiosa. De qualquer forma é a primeira vez que, pelo menos na arte, os pobres são tratados com dignidade.

Para as artes, a maior contribuição da Revolução Francesa foi a idéia de liberdade. Toda a arte moderna $e$, até ccrto ponto, o resultado dessa luta romântica pela liberdade. A autonomia estética e polf́tica incentiva a busca de identidade pessoal e nacional. Daí os traços mais salientes do Romantismo: o conceito de individuo e o senso da História.

O caráter fenoménico do ser é enfatizado já que a existéncia passa a ocupar o lugar privilegiado da essencia. E o homem fica sendo o centro de si mesmo, do sentido do seu viver. $O$ individualismo e o relativismo se opóem radicalmente à tendéncia racionalista dos clássicos para o geral e o absoluto.

A quebra de estruturas repressivas, que sufocam a libcrdade in. dividual, corresponde, na arte, a superaçäo das regras e padrōes cstéticos que davam à arte dos antigos gregos c romanos uniformidade $c$ universalidade. Nāo se trata mais de isolar a obra de arte, purificando-a e protegendo-a de contaminaçōes não estéticas, mas, ao contrário, de mergulhá-la na torrente perturbadora das cxperiencias vitais.

Com o máximo de vibração, os artistas românticos procuram transpor suas experiencias para a linguagem da arte, encurtando ao máximo a distancia entre a emoçāo vivida c a construção da obra. Essa atitude envolve $o$ artista romântico numa séric de clementos conflituosos, que acabaram por definir as características desse novo estilo de viver e de fazer arte. Por outro lado, porem, lcvou os artistas a tomarem consciéncia da sua participaçāo numa realidade social.

Até um Joaquim Manuel de Macedo, por exemplo, em meio a tanta banalidade, revela alguns momentos de profunda lucidez quando focaliza a realidade brasileira: "A miséria é assinalada em Os Dois Amores com senso bastante agudo, que escapa ao sentimentalismo 
habitual das suas páginas e apreende o sentido contraditorio das relaçōes entre pobre e rico. "(1)

Ramificação dos movimentos europeus, o Romantismo Brasileiro foi uma convergência de fatores locais e externos. Coincidindo o seu desenvolvimento com a fase da Independência, a literatura romântica foi considerada parcela do esforço mais amplo de construir a nação fundamentando-se na busca de elementos que pudessem caracterizar o homem e a arte brasileiros. Assim, os românticos iniciam uma pesquisa, que será retomada pclos modernistas, em busca dessas caracteristicas, inclusive na área da língua. Com lentes de aumento, eles focalizam tudo o que pudesse nos diferenciar Jos colonizadores portugueses.

Uma das expressões mais fecundas desse comportamento foi a valorização que fizeram dos poetas da Inconfidencia. E a intensa participação Je muitos na vida pública do país demonstra que esse ideal đe construir a pátria não ficava no papel e nas discussōes intelectuais. Mas, se os estímulos externos cram grandes, reproduzindo um contexto social e polftico semelhante ao que produzira o clima romántico curopeu, faltavam os estímulos internos, pocticos, para que surgisse uma poesia participante, de vulto, o que só vai ocorrer com a terccira geraçäo, a de Castro Alves, scu maior representante. Além de celebrar novos temas, como a liberdade da pátria e a Jemocracia, Castro Alves foi o grande pocta social quando cantou o negro, dando-lhe nāo somente um "brado de revolta", mas, segundo Antonio Cándido, uma "atmosfera de dignidade lírica".

\section{O som revolucionário do Violão de Rua}

A década de 60 ressuscita diversas lendencias vanguardistas do início do século, que haviam tido repercussōes no Modernismo Brasileiro, a ponto de terem sido batizadas de neovangiardas. Enquanto concretistas e praxistas retomavam o experimentalismo estetico, outros grupos reviviam a preocupação com a realidade emergentc, voltando-se para a necessidade de buscar o novo não nas conquistas expressivas e nas rupturas formais, mas na libertaçāo do povo, rompendo com estruturas sociais arcaicas. "O novo $\mathfrak{c}$ o povo", diziam esses jovens que sonhavam com a justiça social.

Esteticamente, csses artistas Jeram um passo atrás, voltando ao Romantismo, quando as preocupaçōes sociais tambem levaram os poetas a pôr o scu canto a serviço de causas externas à arte. IJcologicamente, estavam afinados com novas correntes influenciadas, de um la-

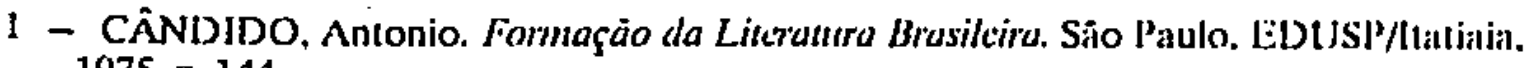
1975. p. 144. 
do, pelo socialismo e, de outro, pelo engajamento político-social do artista pregado por Sartre.

Identificados com o sofrimento das camadas populares da socicdade brasileira, esses artistas incorporam como sua principal funçāo a atividade guerrilheira: a obra de arte é a sua arma para sabotar os circuitos ideológicos dominantes. Ser guerrilheiro e ser artista de vanguarda torna-se a mesma coisa: instaurar o caos no cotidiano das elites burguesas, levando as massas ao poder, é o objetivo de ambos.(2)

Havia realmente muito de romántico no idealismo com que se cultuavam os heróis revolucionários, como o médico guerrilheiro, Ernesto Guevara, o famoso Che que, ao lado de outro mito, Fidcl Castro, iniciara a primeira revoluçăo socialista no continente. Os jovens sc identificavam com seus ídolos e sonhavam, empunhando uma arma ou dizendo um poema, com a liberdade dos povos latino-americanos.

No Brasil, as massas populares ganhavam terreno no processo político desde o populismo de Getúlio Vargas, com o Estado Novo, mas nunca tinham sido mobilizadas com tanta intensidade como no governo de Joăo Goulart, quando diversos setores intelectuais, operários, estudantis, trabalhadores do campo e até militares se uniram para uma radical mudança na sociedade. Entrc cles cstavam os jovens ligados aos Centros Populares de Cultura e a UNE (União Nacional dos Estudantes).

Em suas reflexōes sobre a sociedade brasileira e a cultura popular, esses jovens concluem que a dominaçāo das minorias sobre as massas nāo se limitava à economia, mas atingia a área dos sentimentos, dos valores, das aspirações, da sensibilidade e da vontade. Cabia, cntāo, aos artistas do CPC inverter esse quadro: como "armas espirituais da libertação material e cultural do povo" (3) eles constituíam uma força modificadora do ser social.

Como os poetas románticos, esses jovens revolucionários atribuem-se uma missāo superior: a de conduzir e libertar o que chamam de povo brasileiro. O eu lírico se identifica com o coletivo. O poeta se transforma no bardo, no guia espiritual. Alćm disso, há outro ponto em comum com os românticos: o sentimento nacionalista, muito forte na fase em que as esquerdas e a burguesia nacional se deram as mãos para expulsar o capital estrangeiro.

Entre 1962 e 1963, o CPC promoveu a ediçāo de uma antologia, cujo criterio de seleçāo foi unicamente social, conforme a nota de

2 - HOLLANDA, Heloísa Buarque de. Impressōes de riagcm. CPC, vangutarda e desinude: 1960 70. Săo Paulo, Brasiliense, 1980.

3 - MARTINS, Carlos Estevam. Anteprojeto do Manitesto do Ceniro Popular de Cultura. In: Heloísa Buarque de Hollanda. Op. cit. p. 132. 
apresentação: "visa divulgar poetas que usam seus instrumentos de trabalho para participar, de modo mais direto, nas lutas em que ora se empenha o povo brasileiro, revolucionariamente voltado para as exigências de um mundo melhor e mais humano. "(4) Daí a heterogeneidade dessa coleçāo que arrola poetas de várias geraçōes e tendências.

Só é possível compreender o valor de Violño de Rua situando-o no projeto que procurava fazer uma arte útil, com enfase em objetivos didáticos e doutrinários, em detrimento do fazer poético. Nesse deslocamento a poiesis levou desvantagem e a literatura brasileira ganhou aleijōes mas, em meio àquela panfletagem ingênua, sobressaem poemas de grande beleza, justamente quando o elemento social, incorporado entre os demais estratos poéticos, ganha funcionalidade e rendimento estético. Affonso Romano de Sant'Anna, Félix de Athayde, José Carlos Capinam e Cassiano Ricardo assinam alguns desses poemas.

O que nos interessa aqui, porém, sāo justamente os poemas que, por supervalorizarem a mensagem social, aproximam seus autores dos románticos do século passado.

Paulo Mendes Campos, por exemplo, explora cuidadosamente as técnicas populares no "Poema para ser cantado" (5). Com estrofes regulares de oito versos, em redondilha maior (um dos metros preferidos pelos poetas populares), o poemá testemunha a presença de elementos românticos, dos quais o mais significativo é a concepçāo do poeta como um herói libertador, identificado com as dores do povo, sendo este último, por sua vez, idealizado como entidade homogénea, unida pela igualdade e fraternidade, marchando para conquistar um ideal superior, ou seja, o estabelecimento da justiça social.

Bastante brega aos nossos ouvidos pós-modernos, acostumados com a sofisticação da linguagem poctica dos anos 80 e totalmente surdos aos apelos sentimentais populistas, o "Poema para ser cantado" incorpora o gosto e o estilo de seu público-alvo, em perfeita consonância com os ideais de conduzir as massas. $O$ canto de vitória do povo ecoa por todo o poema, pelo simbolismo sonoro no jogo das sibilantes, vibrantes, nasais - sem falar na evocaçăo de instrumentos musicais. Tambores e cornetas acompanham essa marcha vitoriosa do povo:

"Nas maremas nordestinas,

Nas ratoeiras das minas,

Nas falazes leopoldinas,

O povo nāo morrerá.

4 - Violäo de Rua. Rio de Janciro, Civilizrçăo Brasileíra, 1962. Vol. l. p. 4.

5 - Idem. p. 64-7. 
Usineiros de acidez,

Manganões de manganês,

Fabricantes de aridez,

Sei que o povo viverá."

O 4\% e o $8^{\circ}$ versos se repetem, estrategicamente, no mesmo lugar, enfatizando a oposiçāo "morrer $x$ viver", numa mensagem otimista. Apesar do ritmo ingenuamente alegre, as dez estrofes descrevem, exaustivamente, todas as injustiças, torturas, espoliaçōes, opressōes e sofrimentos impingidos às camadas pobres da população. A regularidade dos versos, o mesmo esquema rímico - AAABCCCA - e rítmico (todos os versos tem acentuação na 3ạ e 7â sílabas) e a similaridade das estrofes universalizam os problemas do povo: nāo é só no espaço nacional que ele sofre, mas em todo o mundo: "No Brasil, na Argentina,/USA, Cuba, França, China"... Rimas internas, paralelismos, anáforas ajudam na exploraçāo das inúmeras conotações sugeridas pelo vocabulário. Todos os planos se fundem nesse vibrante canto de vitória.

A mesma valorização da mensagem social ocorre também no poema de Vinícius de Morais, "Os Homens da Terra" acompanhado da seguinte epígrafe: "Em homenagem aos trabalhadores da terra do Brasil, que enfim despertam e cuja luta ora se inicia".

É justamente o "início dessa luta" que dá forma ao poema $\mathrm{cm}$ todos os níveis. Estrato fónico, unidades de sentido, unidades rítmicas, rimas, imagens, tudo isso compōe uma trama bem tecida em torno dc uma oposiçāo básica: donos de terra $x$ trabalhadores. A construçāo do poema segue um modelo rigidamente dialético, onde a tese é a exploração, a antítese é a escravidăo e a síntese, a revoluçāo.

\footnotetext{
"Senhores Baröes da terra

Preparai vossa mortalha

Porque desfrutais da terra

E a terra $C$ de quem trabalha

Bem como os frutos que encerra

Senhores Baróes da terra

preparai vossa mortalha

Chegado é o tempo de guerra."
}

Há todo um vocabulário específico que compõe o mundo dos senhores da terra, que agora começa a ser ameaçado. $O$ vocativo do primeiro verso é repetido ao longo de todo o pocma, mas com algumas variaçóes que, além de quebrarem a monotonia, mostram as inúmeras nuances da exploraçāo bem como a sua amplitude. A terra é a palavrachave que une os dois eixos estruturais do poema: cla deve pericncer a quem trabalha mas está nas māos de ociosos. Essa é a maior injustiça, o motivo primeiro da revolta: "Porque desfrutais da terra/E a terra $c$ de quem trabalha./Bem como os frutos que encerra." Do confronto 
entre a mesquinhez dos senhores de terra e do sofrimento intenso dos trabalhadores só se pode chegar a uma grande revolta: a "nossa guerra", diz o poeta, totalmente identificado com a luta do campones e do operário. O poeta fala para o povo em nome do povo.

\section{Os abismos da alma: o negativismo romantico}

Uma corrente tão desenvolvida dentro do Romantismo, o negativismo ficou conhecido como o mal do século, passivel de ser explicado de diversas maneiras, sob diferentes enfoques. Uma delas diz que o poeta, tentando exprimir a natureza, em toda a sua grandeza, sentese incapaz. Isso criaria uma consciencia de desajuste, Jecorrente da desconfiança diante da palavra. Dal o đesejo de fuga do real, já que este nāo pode ser expresso pela palavra humana. A própria vida lhe parece, assim, um mal. Entretanto, por trás desse desajuste e da inadequação da palavra existem problemas mais complexos, derivados de um mergulhar profundo nos abismos da alma humana, que trouxe como conseqüencia uma onda de pessimismo e sadismo responsável por uma das manifestaçōes mais originais do espírito romântico.

A negaçāo e a revolta contra valores sociais, quer pela ironia e o sarcasmo, quer pelo ataque desabrido, remontam às origens do Romantismo, sendo encontradas já no movimento alemāo Sturm und Drang, que o precedeu, preparando seus caminhos. Antes de ser ruptura estética, a renovação romântica foi, com Rousseau, ruptura moral, social e política: ser romântico era viver de uma determinada maneira, abrir-se sem reservas para a vida afetiva, desembaraçar-se das convençōes sociais, nāo consentindo que a coletividade, por intermédio de forças reguladoras como a razāo e a vontade, sufocasse a espontaneidade do instinto e a sabedoria natural do sentimento.

A conquista dessa liberdade do individuo nas artes nāo $c$ um fato isolado, mas acontece, nessa época, em todos os segmentos da sociedade. Pode-se até fazer um paralelo entre o princípio da livre concorrência e o direito à iniciativa privada da áréa económica e a tendéncia do escritor expressar seus sentimentos subjetivos, pondo $\mathrm{cm}$ cena sua personalidade e fazendo do leitor uma testemunha dos seus conflitos intimos. Muitas vezes esse individualismo se transforma em protesto contra a mecanização da sociedade industrial e contra a despersonalizaçāo da vida ligada à economia do laissez-faire.

Assim, a atitude do poeta romântico diante da socicdade $c$ ambigua: de um lado, ele pode se identificar com o coletivo, num protesto contra o poder estatal e o domínio das classes privilegiadas; de outro lado, porém, ele pode se revoltar contra o coletivo, vivenciando um profundo conflito entre seu ideal de personalidade e o processo da cultura.

De qualquer forma, os românticos revelaram uma coragem sem 
precedentes ao descerem aos subterráncos da vida afetiva e da vida social. Foram fundo nas experiencias conflituosas do indivíduo, trazendo a tona, muitas vezes, contextos muito proximos da loucura. Tais experiencias sempre foram acompanhadas de uma permanente reПlexão sobre o infinito, a morte, a angústia, a dúvida, misturando admiravelmente intuiçāo e fantasia com incrível lucidez analítica.

Byron simboliza muito bem a estética dos contrários que ć o Romantismo: é um exemplo perfeito da tendencia para o desmedido e contraditório ao fundir em $O$ Manfredo aspectos aparentemente inconciliáveis do comportamento. É por isso que o mal do século também ficou conhecido como byronismo, representado no Brasil principalmente por Álvares de Azevedo. Trata-se de uma literatura que sc caracteriza pela volúpia dos opostos, pela filosofia do belo-horrível, da devassidão e da melancolia. A linguagem, scmpre expressando diretamente as emoçōes é marcada pela falta de equilíbrio, pela pressa, pela improvisaçāo, scm muita preocupação com a construção da obrá.

Na sua forma a obra de arte romântica é sempre aberta, incorporando com frequencia o fragmentário e o inacabado. Se o discurso literário elássico procurava ser fator unificador do ser, encobrindo a divisão, o desequilíbrio, o texto romântico, ao contrário, póc à mostra a divisāo do ser, o desequilíbrio, a fragmentaçăo no seu próprio corpo. Aos temas preferidos das ruinas, da morte, da angústia, do desajustamento social, da cisāo interior correspondem as formas inacabadas c fragmentadas.

Debruçados sobre si mesmos, os românticos deparam-se com os misteriosos conflitos interiores. Sentindo-se a margem da sociedade, como alguem dissociado dela, experimentam o estranhamento, o desconforto, o tédio e uma estranha sensaçāo de desterro. Por outro lado, a consciencia dessa cisão interna leva-os a uma intensa busca de unidade, de sintese, de fusão absoluta com o universo. $O$ infinito torna-sc uma obsessão para os românticos e aumenta mais ainda a angústia c o niilismo. E, uma vez que o infinito não pode caber no finito, a obra de arte também nāo pode fechar-se como um todo perfeito c acabado. A solução é adotar formas abcrtas. Com eles, a obra de arte deixa de ser perfeição objetiva para se tornar explosão subjetiva.

\section{Um novo nial do século}

Os famosos versos de Allen Ginsberg - "I saw the best minds of my generation destroyed by madness" - são representativos de uma geração que ficou conhecida como Beat Generation, nos EUA dos anos cinquenta, quando o quadro político internacional se caracterizava pela guerra fria, como se chamou o confronto entre capitalismo c comunismo após o término da Segunda Grande Guerra. 
Embora não comprometidos com nenhum programa de transformaçāo ou revoluçāo social com base no marxismo, esscs jovens traziam novo estilo de contestação da sociedade capitalista: "A utopia por eles desencadeada ficou sendo, portanto, uma ' revoluçāo' a nível de uma certa minoria social, predominantemente de classe média, existindo numa posiçāo marginal e periférica dentro do sistema capitalista, assumindo posturas, imediatas e radicais, de contestaçāo, em termos de contrapor uma gama muito variada de novos comportamentos e valores aos valores e comportamentos estabelecidos. "(6)

Com diversos desdobramentos na década de 60 , essa "revolução" ultrapassou as fronteiras dos EUA, difundindo-se como rebelião juvenil internacional, sendo depois absorvido pelo sistema. As calças desbotadas, por exemplo, usadas pelos jovens dentro de um estilo de agressiva contestaçāo passaram a ser vendidas pelos fabricantes de jeans.

A palavra underground, fundamental para se compreender esse movimento significa uma comunidade socialmente minoritária que, habitando os subterrâneos do sistema social, tem como objetivo fazer circular uma informação desvinculada do esquema institucional cstabelecido pelos grupos que detem o poder. Dessa forma se pretendia lançar as bases de uma nova cultura, freqüentemente denominada contracultura.

Se, para os revolucionários ligados ao marxismo, o capitalismo trazia em si contradiçóes que levariam à sua própria superação histórica, para esses jovens rebeldes nem essa esperança scria possívcl, já quc tan to o capitalismo quanto o comunismo a poiavam-se numa cstrutura desumana e destruidora. Se nāo valia a pena se engajar nas lutas contra o capitalismo, a divulgação recente dos horrores do stalinismo demonstrava que o socialismo também não merccia confiança.

No Brasil, tivemos, na decada de 70 , uma espécie de réplica nacional do underground. Foi a época da contraculiura, marcada pelo intenso consumo de drogas, pela valorizaçăo đa psicanálise, pclo culto ao corpo, ao rock, e aos circuitos alternativos. A imprensa alternativa, por exemplo, floresceu com periódicos como Pasquim, Flor do $\mathrm{Mal}$, Bondinho, $A$ Pomba c outros, cujo objetivo era romper com os principios de prática jornalística estabelecidos pela grande imprensa, deixando de lado o tom neutro, objetivo c assumindo um discurso que não dissimulava a parcialidade.

Julgando a participaçāo política da geraçāo anterior uma caretice, csse jovens substituem os jeais de prática política pela valorizaçāo de novos comportamentos, que levassem a uma radical mudança de

6 - BUENO, Andre Lufs. Contracuhura. As uropias em mancha. Rin de Janciro. PUC, Depto. Letras, nov/1979. p. 5. Dissert. Mestr. (mimeo). 
vida. Náo acreditavam em qualquer possibilidade de revoluçāo social sem uma transformaçāo individual. Não sentindo mais qualquer identificaçāo com as massas, trocam os idolos guerrilheiros pelos cantores de rock, buscando inspiração nas minorias marginais (homossexuais, negros, marginais de morro, pivetes).

A rebeldia e o pessimismo cultural desses jovens têm muito da atitude romântica como demonstram os temas cultuados por eles: liberdade, desrepressăo, procura de autenticidade e liberação de sentimentos e instintos. $O$ individualismo exacerbado acaba no irracionalismo e a supervalorização da experiencia de vida transposta para a arte, com o mfnimo de preocupação com a forma, levam esses jovens a ver na poesia uma curtiçăo existencial. A ingenuidade, o tom irónico, o cinismo, a fragmentaçāo do eu e dos textos, as contradiçōes, a melancolia mórbida e o misticismo sāo outros ingredientes que mantçm o parentesco desses poemas extremamente subjetivos com o Romantismo. A curiosidade com relaçāo a correntes esotéricas e religiōes orientais leva-os também, como ocorrera com os românticos do sćculo passado, a certo fascínio pelo espiritualismo e até pelo satanismo.

O sistema é constantemente agredido pela subversão da linguagem e pelo comportamento. Há uma identificação total com o mundo do rock: mais do que um género inusical, estc é adolado como um ritmo de vida, uma maneira nova de pensar as coisas, a sociedade. $O$ rock representa a liberação do corpo e da mente, a percepçăo moderna, a marginalidade.

Nesse empenho de encontrar nova forma de pensar o mundo, a loucura também tem um papel importante, sendo vista como um caminho alternativo, capaz de romper com a lógica racionalizante da esquerda e da direita. Infelizmente, porém, a experiência da loucura nem sempre foi simples experiência literária: com a radicalizaçāo do uso de tóxicos e da exacerbaçāo das experiências sensoriais e emocionais, eram frequentes os casos de internamento e até suicídios, bem pouco estéticos.

A rejeição do sistema, que abalou todas as instituiçōes sociais, bem como a descrença com relação à esquerda ocorrem num momento de desilusóes com a política, quando os movimentos de massa são novamente derrotados pelo regime que decreta o AI-5. Alcm da intensificação da repressāo policial no país, o quadro internacional sugerc novas desilusócs: a invasāo da Tchecoslováquia nāo dcixa dúvidas quanto ao totalitarismo soviético. Intensifica-se também $\mathrm{cm}$ Cuba a repressão d̀ artes, aos homosscxuais etc. "Instala-sc a desconfiança em todas as formas de autoritarismo, inclusive os que sāo exercidos $\mathrm{cm}$ nome de uma revolução e de um fruto promissor, promovendo a valorização política de práticas tidas como alienadas. O moralismo comunista é recusado como uma aititude de 'salāo ' que resguarda o corpo, 
teme as forças revolucionárias do erotismo e evita pensar as próprias contradiçocs. " (7)

Torquato Neto, que participou do Tropicalismo, compondo diversas músicas com Gilberto Gil e Caetano Veloso, foi um dos lfderes mais idolatrados dessa geração. Sua letra mais famosa foi Geléia Geral, inspirada na denominação que Décio Pignatari fe z da poesia brasileira, na revista Invençăo, no 5, em 1966. Assinava uma coluna no Última Hora, com o mesmo título. Suicidou-se em 1972, deixando um bilhete tão sucinto quanto repleto do espírito negativo de sua geração com relaçāo à sociedade e à vida: "Pra mim, chega". Scus textos, pocmas e prosa, foram reunidos no volume de publicaçāo póstuma, Últimos dias de Paupéria, espécie de bíblia das novas geraçōcs.

Enfatizando os temas da loucura e da morte, o livro apresenta textos onde se misturam a poesia, a prosa, a fragmentaçāo, a ironia $\mathrm{e}$ a agressividade. Suas contradiçōes e obsessōes afloram numa cxpressāo espontânea do "eu " em cstilo romântico: indivichualismo exagerado, valorizaçāo da experiência vital, aceitação do lado indisciplinado, "desferrolhado", do sèr, fragmentação intcrior são marcas desse estilo.

\author{
"Cogito \\ eu sou como eu sou \\ pronome \\ pessoal intransferfvel \\ do homem que iniciei \\ na medida do impossfvel \\ eu sou como eu sou \\ agora \\ sem grandes segredos dantes \\ sem novos secretos dentes \\ nesta hora \\ eu sou como eu sou \\ presente \\ desferrolhado indecente \\ feito um pedaço de mim \\ eu sou como eu sou \\ vidente \\ c vivo tranqüilamente \\ todas as horas do fim".
}

A despeito dos pontos scmelhantes, existem também inúmeras diferenças entre esta geraçāo e as geraçōes románticas do século pas-

7 - HOLLANDA, Heloisa Buarque de. Op: cil. p. 69. 
sado. Talvez uma das maiores seja a supervalorização do presente. $O$ aqui e agora é o imperativo máximo de nossos jovens, enquanto os primeiros romanticos viviam sonhando com o passado ou com o futuro. Entretanto, é preciso observar que o poeta de "Cogito" vive csse presente como um "vidente", e, nesse presente, vive "todas as horas do fim". Portanto, já não é o presente normal que ele vive. É como se o tempo cronológico fosse abolido, trazendo todo aquele misterioso fascínio dos românticos pelo eterno. Isso demonstra também um relacionamento contraditório com o presente, com o seu momento de vida, o que enfatiza a angústia $\mathrm{e} o$ niilismo.

A negatividade aparece frequentemente no tema da morte que, paradoxalmente, $e$ vista como um bem, uma libertação do mal que, no caso, é a própria vida:

"Quando Chegar

Quando eu morrer,

Anjos meus,

Fazei-me desaparecer, sumir, evaporar

Desta terra louca

Permiti que eu seja mais um desaparecido

Da lista de mortos de algum campo de batalha

Para que eu năo fique exposto

Em algum necrotério branco

Para que não me cortem o ventre

Com propósitos autopsianos

Para que nāo jaza num caixāo frio

Coberto de flores mornas

Para que não sinta mais os afagos

Desta gente táo longe

Para que eu não ouça reboando eternos

Os ecos dos teus soluços

Para que perca-se no éter

O lixo desta memória

Para que apaguem-se bruscas

As marcas do meu sofrer

Para que a morte só seja

Um descanso calmo e doce

Um calmo e doce descanso".

Esse melancólico poema foi escrito pela jovem Ana Cristina César que um dia se cansou de cantar a morte e se jogou ao seu encontro, de uma janela, dois meses depois de ter registrado: "Estou vivendo de hora $\mathrm{em}$ hora, com muito temor./Um dia me safarci - aos poucos me safarei, começarei um safari. "(8) E foi assim que ela "se safou" da frag-

8 - CESAR, Ana Cristina. Ineditos e dispersos; poesia/prosa. São Paulo, Brasiliense, 1985. p. 181. 
mentação de um mundo louco, encontrando, enfim, o equilíbrio: "Agora, imediatamente, e aqui que começa o primeiro sinal/ do peso do corpo que sobe. Aqui troco de măo e começo a ordenar o caos." (9)

No Romantismo, muitas vezes, o negativismo, aliado ao fascínio pelo mundo do oculto, das trevas mesmo, leva a uma evocação mórbida de satanismo. Isso também está presente entre os jovens marginais dos anos setenta. Nāo falta nem mesmo o célebre tema da "venda da alma" ao demónio retomado por Chacal, outro poeta dessa geração, embora num tom irônico de desmistificaçāo. O tratamento dado ao tema, porém, se por um lado o despoja da aura romântica da ambigüidade, do conflito e da dilaceração interior, ganha, por outro lado, um efeito corrosivo como crítica aos valores judaico-cristãos da sociedade burguesa. Aliás, nāo é bem contra esses valores que ele investe, mas contra a hipocrisia de uma sociedade que, pregando a fraternidade, a justiça, a bondade etc, comete as maiores barbaridades contra os indivíduos.

O texto citado chama-se "Barganha Belzebu" e foi publicado no livro Comício de Tudo: o personagem vai penhorar a alma e fica decepcionado ao saber que o diabo já não se interessa por almas virtuosas. "Ora, meu caro idiota, da sua confecçăo, meu chalé anda cheio. Justiceiros renegados, caçadores de recompensa, franciscanos desbundados estão aí a dar com pé de cabra. Na tabela ali na parede, pode conferir, só um tipo de alma está valorizada. A dos portadores de misteriosa malandragem dos morros, becos, buracos urbanos. Desses mestre-salas clandestinos, desses dignos representantes do breque c do brilho, desses sim será o Reino das Sombras".

Em outro poema de Ricardo de Carvalho Duarte (Chacal), do mesmo livro vemos um tema que revela o mesmo gosto pelo mórbido:

"Vamp

a rua escura deserta acclera o desejo

eu piso fundo no mundo

com o farol aceso

uma sirene: polícia

no retrovisor

nāo sei se é paranóia

ou se sou infrator

em cada curva fechada espero pelo pior estranho cheiro de sangue ninguém ao redor

no carro, o rádio anuncia mais um assassinato vejo seu corpo na esquina paro o carro e salto

9 - Idem. Ibidern. p. 192. 
Como vou te esquecer seu beijo e mesmo assim marcas no pescoço dizem que o tempo todo só queria assistir a meu fim um dia seu nome é Ana no outro dia Janette o tempo todo na cama afiando a gilete".

O satanismo e os temas mórbidos, que evocam assassinatos, orgias macabras, sáo formas de protesto, de agredir a sociedade. Isso fica muito claro, também, numa especie de manifesto punk publicado pelo mesmo autor na obra já citada:
"punk + a contribuiçăo milionária de todos os erros
o desespero cosmopolita de todos os
meninos/meninas + punk
punk + a vingança vindo a cavalo nas asas de um
aviāo
punhos cerrados caras fechadas fogo cruzado + punk
punk + o eco do capitalismo selvagem da
impunidade burguesa
um jeito de corpo um corpo torcido estilhaço + punk
punk + a resposta da vida contra a morte chamada
sistema

de agora em diante cada vidraça corre perigo + punk

punk + vândalos bárbaros vickings devorando

qualquer lógica

o obsceno abscesso do $\mathrm{ABC}$ contaminando cartilhas

cristās + punk

punk + pluriúnico prazer de ser livre e feroz

agora

todos os projetos para simular o massacre deram

em + punk

punk + um plug ligado na sintonia do satânico

espírto elétrico

a sociedade em chamas pánico em Sāo Paulo + punk

punk + a burguesia que se cuide lá vai lata

é sempre em vão varrer a sujeira para baixo do

tapete + punk"

Mero arrolamento de temas, o "poema" deixa uma sensaçāo de algo inacabado. O negativismo $e$ intenso: já que a sociedade faliu, $c$ bom que se destrua tudo, liberando todos os "crros", todo o primitivismo e fúria dos "vândalos", todos os instintos selvagens, decretando guerra ao mundo, dando um "tiro na jugular da razāo" e dizendo um sonoro "nāo" ao sistema.

Waly Sailormoon (pseudonimo de Waly Salomão) ć outro poeta marcante da geraçăo marginal, tanto por sua atuação combativa, quan- 
to pelo tipo de texto que produziu. Publicou, em 1972, Me Segara Que Vou Dar Um Troço - texto ambíguo, fragmentário, oscilante entre vários pólos e pendendo, quase sempre, para os impasses e as desagregaçōes, ora refletindo problemas pessoais, ora abordando temas de maior amplitude, como a condiçāo subdesenvolvida e colonial do Brasil. Definindo criação como o ato de encaixar tudo e nāo se definir por coisa alguma, mistura em seus textos o niilismo, as hipóteses místicas e apocalípticas, a morbidez romântica, o narcisismo auto-promocional, com sugestōes de uma moral nietzcheana, individual, do mais forte vencendo o mais fraco e negando sempre a idéia de poesia como construção. O tempero final é dado pela profunda descrença no processo político do país.

Navilouca, a principal publicaçāo em conjunto do grupo foi organizada por Torquato Neto e Waly Sailormoon, reunindo textos de muitos poetas, artistas plásticos, músicos, cineastas, o que mostra o intercámbio entre as artes praticado por esta geraçăo, fa to que reforça o parentesco deles com os románticos que iniciaram, no século passado, nāo só a mistura dos gêneros mas também o diálogo entre as diferentes manifestaçöes artísticas.

O nome desta publicação foi sugerido por Stultifera Navis, navio que, na Idade Média, circundava a costa européia, recolhendo os idiotas da família, os desgarrados e fora da ordem. Navilouca tambem recolhe a intelectualidade desgarrada, louca, marginal. Seus viajantes estāo fora mas, ao mesmo tempo, dentro do sistema e essa ambigüidade se revela no próprio projeto sofisticado da publicaçāo: o tratamento gráfico obedece a um nivel técnico semelhante ao das revistas industriais, mas os textos marcados pela fragmentação, pela crítica anárquica, pela rebeldia dos temas e pelo desprezo à forma, introduzem elementos de resistencia nos canais legitimados pelo sistema. O tema central é a marginalidade: nas fotos de qualidade técnica excelente, os poetas aparecem vestidos de vampiro, travestidos $\mathrm{em}$ homossexuais, ou à moda da imprensa sensacionalista, com barras pretas nos olhos, encostados em muros ou em automóveis antigos, com pose de gangsters. A palavra "gilete", muito comum nesses textos 6 um dos elementos utilizados para revelar ambigüidade: pelas múltiplas conotaçōes, cla significa ora arma de crime, utilizada por pivetes, ora um objeto de cmbelezamento, ora, como na gíria, um ser bissexual - "concreção de ambigüidades; que lado da gilete você prefere? sāo os dois iguais? o corte e cego ou invisível? pra barbear ou castrar?"

Os poemas tematizam a nova sensibilidade, uma das buscas desses artistas, como demonstra o poema de Jorge Salomão:

"Eu, fragmento de uma sensibilidade que produz um ritmo

$\mathrm{Eu}$, que vim ao mundo participar dessa missa louca 
com minha doida dança na derrocada dos valores que torturam a alma humana

Eu, filho do sol

$\mathrm{Eu}$, forte, belo, irmăo do poente

Eu, dançando nesses esparsos-espaços palco da vida".

No clima de decadéncia, a adoçăo da loucura ć uma conscqüência da negaçāo romântica da razāo. Ô poeta busca nova sensibilidade inventiva, recusando soluçōes prontas, utilizando uma linguagem mais referencial que poética, que aproxima a arte da experiência vivida. A linguagem também revela fragmentaçāo, descontinuidade, muito mais pela própria experiencia de conflitos interiores do quc como rccursos estéticos. A marginalidade e valorizada pelo que cla tem de amcaça ao sistema, possibilitando um estilo de agressāo e transgressāo. A contestaçăo é assumida conscientemente, revelando-se no uso de tóxicos, na bissexualidade, no comportamento descolonizado . A guerrilha armada é substituída, assim, pelo comportamento tido como ilcgal e agressivo.

\section{A prosa experimental}

Negatividade c fragmentaçāo, duas características importantes na literatura romântica, nāo estâo presentes apcnas na poesia marginal dos anos setenta. Tambcm o romance experimental dessa época apresenta esses aspectos entre suas principais obscssōes.

O livro de Ivan Angelo, por exemplo, $A$ Festa, é tāo fragmentado que suas partes, independentes, podem ser consideradas contos. $\mathrm{Na}$ verdade, porém, é uma espécie exótica de romance feito de contos, que se entrelaçam e se desdobram, pela composiçāo $\mathrm{cm}$ forma dc montagem, onde entram citaçōes, notícias de jornal, discursos políticos, manifestos, letras de música. $O$ descontínuo e o ambíguo sāo levados às últimas conseqüencias, em todos os niveis da estrutura narrativa.

Há um esforço consciente đo autor em não harmonizar os clementos mas ressaltar agressivamente as frestas, os vazios, realçando a natureza fragmentária do texto. Escrever um romance deixa de ser um ato de construçāo, de composiçăo, para se transformar em destruiçăo, decomposiçăo, desintegração do universo ficcional. O real é tão absurdo, que não pode ser captado e/ou transmitido de outra forma. É verdade que a obra de arte tem como objetivo criar uma realidade própria, mas os jovens romancistas dos anos sctenta nāo cstāo preocupados com a criaçāo literária propriamente dita. A obsessảo deles é pelo próprio real, um verdadeiro pesadelo vivido pela sociedade brasileira nessa fase de intensa repressāo política. A arte dcles é documento pungente da realidade. A ficção se faz colada ao contexto exterior. É por isso que, neste livro, o referente político, como uma grande sombra, 
penetra até na vida íntima dos personagens, sendo o principal fio com que o autor costura os fragmentos da narrativa.

Tomando a "festa" como metáfora da socicdade burguesa, o autor questiona e ridiculariza todos os seus valores, desmistificando-os na propria estrutura da obra. As únicas verdades que ele tem a transmitir são as dúvidas e a obscuridade. Nāo fica nada definido, nada ć esclarecido ao perplexo leitor. Tal atitude é a negaçāo absoluta daquele narrador onisciente e poderoso, do grande romance totalizador do seculo passado, reflexo de um autor que tinha visão definida e idéias esclarecidas a respeito de todo o conjunto da sociedade.

Zero, o romance de Ignácio de Loyola Brandão, também utiliza a técnica de montagem, que realça a fragmentaçāo de um real múltiplo e extremamente contraditório. Colagem absurda de rúnas, alegoria da situaçăo violenta e da desagregaçāo de um país, a narrativa incorpora, em ritmo alucinado, os dados do real e o próprio espaço gráfico do livro. $O$ pessimismo e os detalhes degradantes, o grotesco, realçam a degeneraçāo geral da sociedade, em todos os níveis e em todas as áreas.

A aventura do romance experimental também atrai autores veteranos, como Antonio Callado: a fragmentaçāo formal iniciada $\mathrm{cm}$ Bar Don Juan se consolida em Reflexos do Baile, tolalmente construldo em forma de mosaico. Nenhum vestigio da estrutura tradicional: o espaço, o tempo e até o narrador se diluem. Uma colagem de bilhetes e cartas conta a história de um seqüestro político. Sem dúvida a fragmentação se revela de grande eficiência na documentação de uma socicdade dilacerada.

Mas é em Operação Silêncio, de Márcio de Souza, que a obsessāo pclo real abre uma brecha para o drama existencial. Tido como um desajustado, tanto pela esquerda quanto pela direita, o cineasta Paulo Conti vive dividido entre os amigos revolucionários, empenhados na guerrilha, com seus métodos violentos, e o seu próprio método de resisténcia pacílica ao sistema, atraves da arte. Entre o idealismo, a pajxảo mesmo pelo cinema c o materialismo agrcssivo dos companheiros nenhuma conciliação é possível: "Todas as vezes em que pensava cm Patrícia, também nas discussócs políticas dos últimos dias com ela talvez porque prezasse muito as posiçōes polf́ticas dela; cle se queixava que o artista nāo tinha lugar no partido c não havia tarcla de artista para cle".(10)

Autêntico personagcm romântico, teima em sobreviver, dilacerado pelos conflitos intimos. Embora pertencendo a uina geraçāo ameaçada, que acaba inteiramente destruída - todos os seus amigos c

10 - SOUZA, Márcio. Operaçãa silencio. 29 cu. Rio de Janciro, Marco Zero. 1985. p. $106-7$. 
companheiros morrem ou desaparecem na guerrilha - como um estranho no mundo ele sonha em fazer cinema e tem pesadclos reais $\mathrm{cm}$ meio à ditadura militar. "Às vezes elc se sentia como đesses animais que figuram numa lista internacionalmente comovedora."

O dilaceramento interior já nāo se dá por causa do pecado. $O$ conflito nāo e mais entre a matéria e o espírito, um conflito religioso, como na época do Romantismo. Nāo é, porém, menos doloroso o conflito vivido por essas geraçōes atuais, que ganhou conotaçōes políticas e ideológicas.

A atmosfera do romance é mórbida. O tempo algo indefinido flui de modo confuso, sempre escapando ao controle do personagem. A paisagem, tal como a alma de Conti, e sempre indefinida e, como os demais ambientes, sempre sugere tristeza, ruínas e decadencia: "Sim, era agosto, com toda a certeza; o roteiro, os cálculos de produçāo, o elenco. Os generais estavam no Planalto. (...) Deputados, operários, industriais e todo o resto dessa gente; envoltos neste macio vômito azul escuro da manhã, vômito que durante o dia o sol não perdoará, revolverá com o vento, dispersará pelo chão e pclos rostos dos que passam, caminhantes quase levitando de anonimas amarguras. (...) ... a cidade era assim, sempre fora? Uma vocação insensível e dolorosa, com a sua adorável imitaçāo de decádencia (e os cintos apertam-sc na voz dos oficiais) onde todos estavam obrigados, todos, a arrastar suas aspiraçóes como se náo fossem mais que absurdos de pouca credibilidade... (...) Que estranho viver em agosto, ao entrar no centro comercial sem nunca ter saído da cidade, neste silencio implosivo de todos os ruf́dos; o vômito; o suor envergonhado; os pardais voando para as árvores empoadas de fumaça pestilenta, as baratas felizes nos esgotos..."(11)

Personagem conflituoso, Paulo Conti sobrevive dividido entre um negativismo extremo e uma esperança absurda. É um autentico herói romântico, terrivelmente angustiado, superando as contradiçōes e as opressōes, do seu interior ou do mundo, numa corajosa operação silêncio, conforme indica o t́́tulo do livro. Sentindo-se permanentemente um fracassado, medroso e sem vontade de enfrentar a luta, ele acaba vencendo os fantasmas proprios de um sobrevivente, o medo e a indefiniçáo, e tem morte de herói, ao enfrentar um general.

Esse final, porém, como toda a história do livro, nāo fica muito claro, sendo passivel de outras interpretaçōes, porque a linguagem $c$ de tal forma fragmentada e tantas linhas de narrativa se cruzam, que $\mathfrak{c}$ diff́cil uma compreensão lógica do enredo. A desarticulaçāo entre as partes é total. Na primeira parte do livro, por cxemplo, os subtítulos

11 - Idem. Ibidem p. 2. 
dos mini-capítulos nāo têm, aparentemente, nada com o quc neles $\mathfrak{c}$ narrado. Enquanto os subtítulos se referem a episódios da revolução comunista na China, os micro-textos apresentam flashes da vida de Paulo Conti, numa decomposiçāo cubista da narrativa.

\section{Conclusão}

Nāo se pode dizer que a literatura brasileira dos anos sessenta e setenta tenha qualquer propósito de repetir o Romantismo do século passado. Mesmo quando um estilo se repete na história, como o Classicismo, que volta em dois períodos distintos, Renascimento e lluminismo (Neoclassicismo), sempre há novas experiências, que enriquecem ou modificam o estilo com outras contribuiçōes. É o caso, por exemplo, da noção de perspectiva na pintura renascentista.

É inegável, porém, a permanência de elementos românticos na literatura brasileira contemporánea. Mesmo no contexto histórico esses elementos estāo presentes. Tanto no período romântico, como na fase da contracultura e da poesia marginal pode-se verificar uma intensa transformaçāo política, com derrubada de valores básicos da socicdade. São perf́odos de ataques a instituiçōes políticas, religiosas, sociais tidas como superadas. Sāo periodos de grande insatisfação com a sociedade e de rcivindicaçōes sociais radicais.

Os direitos individuais sāo supcrvalorizados $\mathbf{c} a$ insatisfaçāo com a vida social se manifesta de duas maneiras básicas. Na primeira, de modo positivo, quando a rebcldia é canalizada c dirigida para a rcconsIruçăo da socicdade, através da luta, inclusive armada, já que só uma revolução podcria estabclccer a justiça e a liberdade. Neste caso, o pocta se transforma num herói, portador de vcrdade redentora $\mathrm{c}$ de poder para combater as trevas das opressðes polfticas e sociais. Ncssa linha se encaixam os artistas brasileiros ligados aos centros populares de cultura nos anos sessenta, entre os quais incluímos os poctas de Violīo de Rua.

No segundo caso, a revolta se dilui negativamente, infiltranido-se por tudo, de mancira corrosiva. O artista cxorcisa todos os demonios, seus e da coletividade, soltando tudo o que estava reprimido. $O$ satanismo, por cxemplo, quando é cvocado pelo jovem marginal, já nāo tem mero sentido espiritual, adquirindo nova conotaçāo política: ao assimilar o mal, a arte torna-se muito mais corrosiva. Essc novo mal do século continua, porém, o mesmo idcal romântico de libcraçăo do eu de toda opressāo exercida pela comunidade. Infelizmente, cssa rcbeldia morbida acabou levando muitos jovens à autodestruiçăo, sem que deixassem uma herança sólida em prosa ou poesia. Para isso concorreu o fato de terem valorizado mais as experiencias vitais do que o trabalho com a linguagem. O negativismo e a fragmentaçāo foram, assim, mais experimentados na própria vida do que na arte. Produziram, porém, 
como testemunhas de uma época em que o contexto favorccu as manifestaçōes romanticas, os poemas marginais e os romances cxperimentais dos anos setenta e início da década seguinte.

\begin{abstract}
ABSTKACT
A parallel between poets from the $60^{\prime}$ and $70^{\prime}$ and the Romantic Pocts, w/tose common traits come to be in historical contevts marked by political changes, changes in values and institutional changes. Poctic creation reftuts a fragnentany being in search of frcedom who uses art as a weopont of battle $A$ rebelliousnicss which, stich a new "evil of the century", becomes at times auto-destruction Such clements, which orc prescint not onh in the counter-culare and monginal pocts moicments, but also in thcil reactions to a set of social conditions render the vital cuperionces more remorkable than the artistic lcgacy in many of the cases poimted to.
\end{abstract}

Key-words: Romonticism; social pocty; socially committed art; counter-culaurc; Popular Centers of Culhurt: 